\title{
The Study of Brand logos Dimensions on Performance of Ilam National Company of Oil Products performance
}

\author{
Mojtaba Karami ${ }^{1}$ \& Mohammad Aidi $^{2}$ \\ ${ }^{1}$ Master of Business Management, Islamic Azad University, Ilam branch, Ilam, Iran \\ ${ }^{2}$ Assistant professor of management, Ilam University, Iran \\ Correspondence: Mohammad Aidi, Faculty Member of Ilam University, Iran. E-mail: mohamaidi@gmail.com
}

Received: July 2, 2016

Accepted: July 16, 2016

Online Published: August 15, 2016

doi:10.5539/mas.v10n12p165

URL: http://dx.doi.org/10.5539/mas.v10n12p165

\begin{abstract}
Nowadays the brands play such an important role in marketing that some authorities consider them as a complete product and believe that customers buy that brand rather than the products. Therefore recognizing the effective factors in choosing the brands and investigating the functional benefits of brand makes various studies necessary. This study tries to examine the effects of brand names and logos in Ilam Oil products Distribution Company's performance. This study is a survey one with an empirical structure. The sample consists of the constant customers of Ilam Oil products. According to statistic findings 30 variables have been effective in the role of brand and logos in Oil Company's performance. The first group of the variables include the brand's functional benefits. The second our is logo's benefits. The third involves the aesthetic appeal of brands while the other goes to brand identification and customer brand commitment.
\end{abstract}

Keywords: brand logos, brand extensions, customer self-identity/expressiveness benefits, customers' brand commitment, firm performance, functional benefit

\section{Introduction}

Design moves things from an existing condition to a preferred one. Therefore, brands are important intangible assets that significantly influence firm performance. Indeed, Customers can develop deep, meaningful relationships with a brand which result in increased brand purchase, reduced customer price sensitivity and lower marketing prices (Ja'afar, 1390, p. 37). Yet, the harsh business reality for firms remains that customers view many brands as indistinguishable and commonplace. So, a brand is typically served as a means for resolving the problem of indicting uishabity of customers (Barth et al., 2003). As one of the most salient visual elements of a brand, logos facilitate the identification of the brand and its differentiation from competing alternatives. Throughout history, logos have enabled the efficient identification of individuals, for example in ancient china, emperors used a dragon as a symbol of imperial power, and groups and movements like the cross on top of the churches or the swastika on Buddhist temples. However, logos are more than simple tools for identification and differentiation. The Christian cross symbolizes sacrifice and life's victory over death, the Buddist swastilcg embodies auspiciousness and good luck. Therefore, logos can convey key information about the brand they stand for. In fact, prior researches on branding indicate the logos act as the primary visual representation of a brand's general image and meaning.

Consequently, logos can shape the brand's reputation and the customers' attitudes, their purchase intentions, also their brand royalty (Moller, 2003). However, no available research investigates the specific nature of these relationships. This study examines the impact of brand logos on customer commitment and Oil Company's performance and extends current research in three critical ways.

First, this study explores the mechanism through which logos, as the summary representation of what a brand stands for, strengthen customer commitment and oil products distributing company's performance beyond the competing foreign brands.

Second, no previous work studies when logos are more effective at engaging customers beyond enhancing brand identification, this study tries to investigate the role of brands frequently use extension to other product categories to leverage their current customer base, this study explores if the brands of Oil company have such impressions or not. 
the researcher tries to answer the aforementioned differences according to the brand and logo's effects in Oil company's performance as well as the question that whether in Oil company's performance as well as the question that whether the recognizing the brand facilitates the performance of Oil company in Ilam. In other words, what are the effect of brands and logos on the performance of Oil company from customers' view in Ilam province?

\section{Significance of the Study}

Brands have the ability to express and define individuals' actual or desired selves and to differentiate customers' selves from those of others. For example, a brand can reflect various parts of customers' identities like core beliefs or lifestyles. Brands also become relevant to customers by connecting the individual to others who share similar values (Eisingerich et al., 2010). Sina logos visually represent what the brand is and show what it stands for, they have the potential to serve as a focal point of connection for customers by communicating and reinforcing a brand's core values.

In other words, a brand's logo can be a critical tool for conveying a associations between the brand and the self, which in turn helps people to see the brand with as part of themselves. Furthermore, logos provide brands with a face which in creoles a brand's authenticity and intimate appeal to customers. Logos have the potential not only to express such brand-self associations, but also to strengthen them and enhana customers' willingness to exert effort and invest towards keeping their relationship with the brand. The importance of establishing a symbolic association with a brand can be salient in an environment where customers Resent Corporation's that are faceless, but develop a stronger affinity with brands that foster relations with their customers. That's why this study investigates effects of brands and logos on Oil products Distribution Company in Ilam as a new and significant problem in competing conditions with foreign companies.

\section{Brand Logos}

Designing a brand or logo is the process of associating a symbol, sense or a product with customer brand commitment. For instance, Coca Cola has created a significant relationship with its customers through advertising and a specific kind of package. This brand has differentiated itself from its rivals by a special font and using red and white colors in logo.

Different tools, forms and shapes are used in logo-making. Furthermore, brochures, advertisement, cards, catalogs, websites, and packages the domestic or foreign agencies are all critical in reinforcing the relationship between customers and brands. All these can help you make the brand logos known to customers. A brand distinguishes a company in market. Nowadays, brand management is a complex phenomenon. Furthermore, brand management requires a strong background in marketing, advertising strategies, as well as a creative mind in order to achieve new ideas. Brand management is not just making a three dimensional shape of the product but a challenging and difficult imperative (Wan et al., 2013).

\section{Brand Logo Benefits}

No firm designs a brand or logo without considering some benefits. There are a lot of benefits that companies use as a potential to introduce their products, services or even themselves. Some of these benefits come as followings (Park, MacInnis, \& Priester, 2006).

\section{Customer Brand Commitment and Association with the Products.}

Having a brand or logo creates a sense of commitment to the firm and its products. Hence, this commitment makes customers buy the products based on the association not logical reasons. While designing brand logos needs money, customers' commitment and their loyality brings about more financial benefits (Wulf et al., 2001).

\section{Creating Financial Benefit}

Making a powerful brand creates a sense of superiority in customers. I need, designing a brand equals to spending some money.

These efforts finally lead to increasing brand values and in turn, the brand attains desirable financial outcomes (Eisingerich \& Rubera, 2010).

\section{Distinguishing from Rivals}

At brand can have a competing dimension which makes you different from your rivals? The more you spend on designing a brand or logo, the less time you need to convince the customers. The brand helps you to speak about the company and its products more skillfully. It also explains why you are competing in the market and marketing (Wan et al., 2013). 


\section{Convenience in Purchase}

Brand or logos make your purchase decision easier, since they convey tlu most salient benefits. Where you see a lot of products in markets with different features and characteristics, a powerful brand make customers trust in your firm to meet their needs (Wan et al., 2013).

\section{Heightening the Awareness of Customers}

A brand presents your goals and perspectives to customers. For instance, a brand or logo can provide some information about an especial job through some simple words. This really helps raise customers' awareness in the advent of your business (Wan et al., 2013).

\section{Identification and Name}

Brands are designed based on some goals, criteria and skills. These originate directly from what the firms want and promote based on the companies' will. Therefore, making products marked introduce them to customer (Wan et al., 2013).

\section{Familiarly with Brands}

Brand and logos in flange positively customers as well as the individuals who are wt going to buy the prod nets as familiarly brings about interest. Sometimes those who are not customers may want to order some products based on the familiarity. Yours firms' advertisements on buses, the company's pens on your table or reading about you firms advertisement on buses, the company's pens on your table or readying about you firms advertise among colleagues, family members and in offices (Wan et al., 2013).

\section{Brand Extension}

Hawing brand logos can be a great chance to extend your business. If customers are familiar with your brand beforehand, they connect the new product with it, In other words, a well-known brand supports you to introduce new product and services spending a little money (Wan et al., 2013).

\section{Eliminating Rumors}

Making products marked helps to eliminate any doubt from your brand. A negative thought about any product or service will certainly impact its income. In order to decreases the misleading information about your product; you had better make products marked since this will let your customers trust you and this in turn will be a preventive strategy.

\section{Company Owners}

One of the less-known commercial benefits of a brand is making more money using a special brand. Changing the company into a brand name will return to its owners. For example, if the Nike company owners decide to sell the company, buyer should also pay some money for its brand name. This means that a brand makes money for the owners and is also efficacious for those who buy the company.

\section{Less Marketing Expenses}

Evidently you must spend some money on designing a brand: However you can support marketing without spending much money through that brand.

Companies can keep their brands without restating all details in market. For instance, it is Coca Cola to put its logo on any brochure, banner or billboard without explaining about what Coca Cola is as its brand has been fixed as a special $\log$.

\section{Brands and Less Risk-taking}

Having a brand is highly effective in increasing incomes. When customers home to choose between two products, a brand helps to choose the best.

Of course we are talking about the product that the customers are already familiar with. This will reduce the risk in buying and increase the income for the company.

\section{Change in Customers' Tendency}

There are some brand hone fits other than the commercial ones that help customers to have an image of the product. Some events make this image dark and some eve ate tendency in customers toward the brand.

\section{Communication}


Long ago, there were not many choices when customers decided to buy something. Nowadays people are familiar with many products through advertising in media. Nothing can be so effective and manufacturers.

\section{Competing Benefits}

Companies are reluctant to design a brand in economic stagnancy and distress. Hence, research indicates that advertising and designing brand have some competing benefits even in stagnancy.

When the organizations decide to continue advertising, they will increase the confidence of people and in return promote the companies. Therefore, the staff members will trust in the company management and will work more desirably.

Advertising world is constantly growing. You must be careful and aware before any investment designing a brand is a preventive strategy that must be taken into account before any spending. Before designing a suitable brand, you must consider a good message for your markets propose a right logo and a significant brand.

All aforementioned benefits are considers as the main goal of investment in order to make money. These strategies help companies to be more efficient among their rivals.

\section{Brand and Customers' Expressiveness or self-identity Benefits}

Brands have the ability to help express or define individuals' actual or desired selves and to differentiate customers' selves from those of others. For instance, a brand may reflect various parts of customers' identities, such as core beliefs /values or lifestyles they adhere to. Brands also become relevant to customers by connecting the individuals to others who share familiar values or beliefs (Chaplin \& Roedder, 2005).

Since for, they have the potential to serve as a focal point of connection for customers by communicating and reinforcing a brand's core values. In other words, a brand's logo can be a critical tool for conveying associations between the brand and the self, which in turn helps people see the brand as part of themselves. Further-more, as logos provide brands with a face and can enhance a brand's authenticity and intimate appeal to customers, they have the potential to express's such brand-self associations as well as reinforce and strengthen them, thus increasing customers' willing ness to try more and invest resources towards sustaining their relation-ship with the brand. The importance of establishing association with a brand can be particularly critical in an environment but you shield develop a stronger affinity toward brands that encourage self-relevant relations with their customers (Goldman \& Papson, 1998).

\section{Brand Logos and Their Functional Benefits}

Brands can be managed to decrease uncertainty in in divides' lives and enable their selves by facilitating control in attaining desirable outcomes. Hence, brand can create a sense of efficacious selves, helping people handle their daily tasks move efficiently. Logos, that is the visual representations of brands, can remind customers of a brand's functional benefits and communicating such benefits to them. For example, an athlete logo suggests the superior physical from that athlete strive for. Consider Red Bull's logo of two charging bulls in front of a bright sun and the brand's promise to vitalize body and mind.

Given that customers perceive firms that address their needs hence making their lives easier as fair exchange partners and are less likely to switch from these firms. This study explores how logos that convey a brand's functional benefits encourage customers to rely on brands as a solution to certain problems and increase customers' commitment. Brand logos can have the potential to reinforce a brand's promise to assist customers in their lives and logos will strengthen customers' relationships with brands in this way.

\section{Brand Logos and Aesthetic Appeal}

Aesthetic appeal and design have been interesting to human beings and have captured their imagination throughout history. The crafting wit attractive form is as old as human civilization.

Therefore, prior research underscores the role of brands in offering aesthetic qualities in customers. In addition to visual gratification aesthetically appealing brand logos can foster customers to develop an emotional bond with what they perceive as near and perceive as near and pretty 15 them.

Goldman (2005) believes that brands high in aesthetic attractiveness are more likely to connect with customers then brands with low or unappealing aesthetic features. For example, Walt Disney's logo which is the image of a fairytale castle, effectively gives visual gratification and an emotional connection to customers. Hello Kitty, the appealing white cat and a red bow and no mouth, can build deep relations with customers. So, the aesthetic appeal of logos is an essential component of a brand's ability to communicate with them customers, and increasing their commitment. 


\section{Brands and Self-identity or Expressiveness Benefits}

Brand logos can influence customers' commitment through self-identity and explaining their commercial benefits and functional impacts Brands' self-identity make customers think that will have a more efficient life by using their products. As they think the products are unique, this will exert positive influence on their lives.

\section{Brand Logos and Firm Performance}

As De Walf, et al. (2001) suggests commitment, measured as the wailing ness of customers to stay with a brand and to sustain their brand relationship in the future is one of the key measures of strong customer relationships.

Logos help customers identify the brand easily and enable faster decision-making. Brand logos can help the customers to identify and are willing to invest their resources towards keeping a relationship with the brand. A number of factors influence a company's market performance including the firm's strategic insights and how effectively the firm implements this chosen strategy. Hence, one of the hey drivers of a firm's performance is the customers' commitment to the firm's brand. The more loyal the customers are to a firm brand, the more profits the firm gains over time, and this influences the stability and growth of the firm's revenues and effectively protects the firm from competing threats.

\section{Separate Visual Symbols vs. Brand Names as Logos}

Firms frequently decide whether to employ brand name only, like ford or in combination with separate visual symbols as logos for their brands. The visual symbols may personalize a brand and provide customers with a sense of connection more efficiently then what brand names do, because symbols are an effective means of communicating information to people. Since symbols are perceived richer and more tangible than words or names, they work better for brand differentiation. Symbols with an appealing visual design can help brands to become more silent and vivid in individuals' minds and facilitating favorable attitude formation and memory retrieval, and eliciting favorable attitude formation and memory retrieval, and eliciting strong affective and behavioral responses. Symbols more easily signify a brand's benefits and transcend language barriers than words or names. Therefore, brand logos that incorporate visual symbols should be more effective then purely brand name logos as offering self-identity benefits, representing a brand's functional value, and providing aesthetic appeal.

\section{Main Hypothesis}

1. There is a significant relationship between brand logos and the Oil products Distribution Company's performance.

2. There is a significant relationship between Oil company's brand logos and customer self-identity/expressive nesrs benefit.

2.1. The relationship between brand logos and customers' commitment and firm performance.

2.2. The relationship between brand logos and functional benefits of a brand.

2.3. The relationship between visual symbols and brand names and Oil Company's performance.

\section{The Conceptual Background}

Forgave are shows the conceptual model of the study which is taken from study's deceptions and variable: 


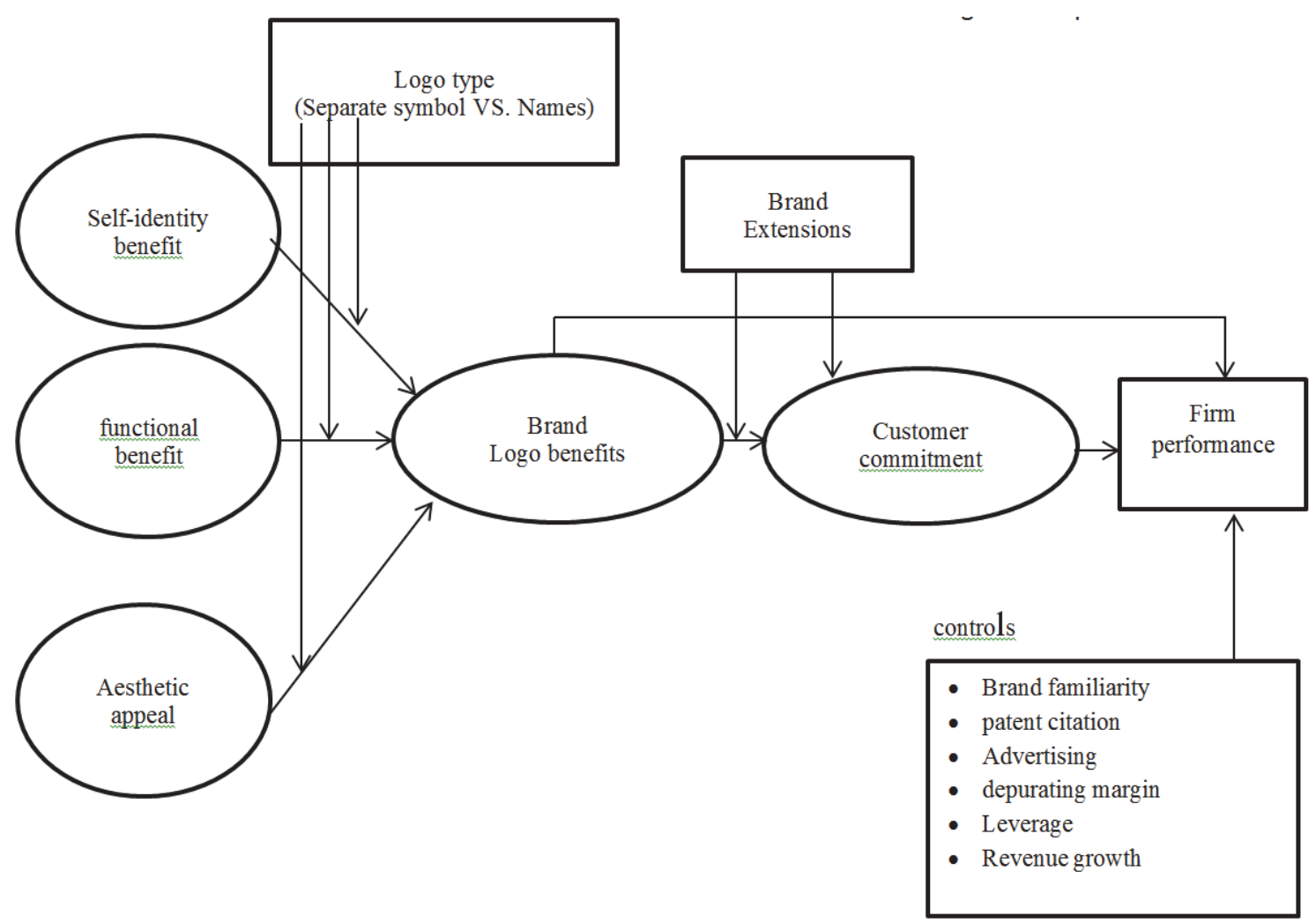

Figure 1. Conceptual model

\section{Methodology}

This study, based on its purpose is a survey one with an empirical structure which explores the correlation. It first describes the features of the population, then goes to the sample. The data of the study comes from some questionnaires. The data provides information to describe the situation and helps to investigate the hypotheses.

\section{Sample and Procedure}

The population of the study involves all customers who use the Oil products. The researchers selected the constant customers became of the large number of the sample who were 120 customers. The sample also includes the Oil company's experts who were41. These experts have at least S years' service in Oil Company. In this study, the researcher drew a stratified random sampling. Stratified sampling, one draws people from each strata who are equivalent in the variables as to decrease the changes in groups. Then they are randomly drawn of each group. In this sampling a criterion is used which is correlated with the variable. In stratified sampling the (n) can be divided in different ways. The more convenient way is equal division between each strata. One may select in proportion to the size of the strata in the population known as proportional sampling. In this study sampling was based on Cochran formula as:

$$
\mathrm{n}=\frac{\frac{z^{2} p-q}{d^{2}}}{\left.1+\frac{1}{N} \frac{z^{2} p-q}{d^{2}}-1\right)} \mathrm{n}=\left(\mathrm{N} \cdot \mathrm{t}^{2} \times \mathrm{pq}\right) \div\left(\mathrm{N} \cdot \mathrm{d}^{2}+\mathrm{t}_{\mathrm{x}} 2 \mathrm{p} \cdot \mathrm{q}\right)
$$

In this formula, the authorized mistake (d) equals 0.05 , with the 0.95 certain, $\mathrm{t}=1.96, \mathrm{p}$ and q equal 0.5 and $\mathrm{N}$ stands for the population. When P equals $0.5, \mathrm{n}$ will invade the most numbers and the best representative sample for the study (Sarmad et al., 1388). In this study with the sample of 120 , the $n$ equals to 91 . And the number of experts which was 41 becomes 37 and the $n$ of the study. Will be 128 people.

\section{Data Collection}

The requisite data and information this research comes from two sources: first, in order to compile the theoretical basis of the study, the researcher used different books, Persian and Latin articles, as well as World Wide Web. Secondly, Some questionnaire were distributed among the participants to collect data as operational research. According to participants' answers, 20 items were written to contain different aspects of brand benefits' scales. 
Then the obtained data were fed into SPSS and were analyzed based on regression.

\section{The Questionnaire Validity and reliability}

A test is said to be valid to the extent it measures what it is supposed to measure or can be used for the purposes for which it is intended (Saif, 1372, p. 182). The validity of the questionnaire was confirmed by the university authorities and professors.

\section{Reliability}

According to Saif (1372) Reliability refers to consistency of a test across different times, it means of a test or measure yield consistent results if it is administered in different times and identical. Reliability usually changes from zero to +1 (Sarmad et al., 1385). In this study the reliability of 20 item questionnaire was measured through Cronbach's alpha formula which is shown in the following table.

Table 1. Cornbrash's Coefficient Alpha and questions based on variables

\begin{tabular}{|c|c|c|}
\hline Variables & Indices & $\begin{array}{l}\text { Cornbrash's } \\
\text { alpha }\end{array}$ \\
\hline $\begin{array}{l}\text { Expressiveness } \\
\text { benefit }\end{array}$ & $\begin{array}{l}\text { Oil company's brand attracts me and the logo helps me to know its products. } \\
\text { The logo doesn't let me attract products just based on feelings. }\end{array}$ & 94.2 \\
\hline Logos Leverage & $\begin{array}{l}\text { Oil company's logo is a symbol of the products that helps me to trust in them. } \\
\text { It guarantees the efficiency of the Oil products. }\end{array}$ & 93.5 \\
\hline Aesthetic appeal & $\begin{array}{l}\text { Brand logos' aesthetic appeal associates positively with customer's } \\
\text { commitment. } \\
\text { Logos can provide customers with sense of aesthetes. } \\
\text { Logos not provide customers with sense of aesthetes }\end{array}$ & 88.33 \\
\hline $\begin{array}{l}\text { Identification } \\
\text { benefit }\end{array}$ & $\begin{array}{l}\text { Brands can create a sense that individuals have better lives by using products. } \\
\text { Brands make us think products are unique; Oil company's success brings } \\
\text { about our success. }\end{array}$ & 97.9 \\
\hline $\begin{array}{l}\text { Customer } \\
\text { commitment }\end{array}$ & $\begin{array}{l}\text { I feel that I show my loyalty to Oil company through using its products. I } \\
\text { keep my purchase even if providing them is more difficult. I may even pay } \\
\text { more for buying Its products. Increasing customers commitment means } \\
\text { increasing information about the brand, not leaving the Oil company alone. }\end{array}$ & 93.2 \\
\hline $\begin{array}{l}\text { Different } \quad \operatorname{logo} \\
\text { symbols }\end{array}$ & $\begin{array}{l}\text { How do you evaluate the Oil company products in comparisons other brands } \\
\text { products? } \\
\text { To what extend can the Oil products conform to your wished? }\end{array}$ & 83.2 \\
\hline $\begin{array}{l}\text { Functional } \\
\text { benefit }\end{array}$ & $\begin{array}{l}\text { The Oil company's services equal to other foreign companies, they are } \\
\text { successful in providing services and doing promises. The services are based } \\
\text { on standards of Oil company. }\end{array}$ & 97.2 \\
\hline
\end{tabular}

\section{1) Data Analysis:}

The data was feint SPSS software and was analyzed in two parts of descriptive statistics and inferential statistics.

Descriptive statistics include frequency, mean, median, mode, deviation, statistic tables and figures. Inferential statics uses one sample kolomogorov_Smirov test to explore the normally of the data and the tests the hypotheses.

2) Analysis and Results:

Participants: Among the sample participants who were 128 people, 21 percent of personnel have got a diploma or certificate, 53.8percent have a bachelor, 25.2 percent have a master of arts degree or higher among the customers, 32.8 percent have a diploma or certificate , 45.4 percent have bachelor, 21.8 percent have a master of arts.

In order to be sure from the statistical analysis resultant be investigate the balance between theoretical comprehensiveness and the data, the structural model was used as follow: 
3) The main Hypothesis:

There is a significant relationship between the brand logo and the Ilam Oil Company's performance.

Table 2.

\begin{tabular}{|c|c|c|c|c|c|c|}
\hline \multicolumn{5}{|l|}{ One-sample test } & \multicolumn{2}{|c|}{$\begin{array}{l}95 \% \text { confidence Interval of } \\
\text { the Difference }\end{array}$} \\
\hline & $\mathrm{T}$ & DT & Sig.(2tailed) & $\begin{array}{l}\text { Meen } \\
\text { difference }\end{array}$ & Lower & Upper \\
\hline Logo familiarity benefit & 46.49 & 127 & 0.000 & 3.20322 & 3.0668 & 3.3395 \\
\hline Logo identification & 43.49 & 127 & 0.000 & 3.23698 & 3.0897 & 3.3892 \\
\hline Brands aesthetic appeal & 47.64 & 127 & 0.000 & 3.35677 & 3.2173 & 3.4962 \\
\hline $\begin{array}{l}\text { Self-identity/expressiveness of the } \\
\text { brand }\end{array}$ & 45.25 & 127 & 0.000 & 3.41276 & 3.2635 & 3.562 \\
\hline Brand Commitment & 48.54 & 127 & 0.000 & 3.27902 & 3.1454 & 3.4127 \\
\hline Brand logos visual symbols & 40.56 & 127 & 0.000 & 3.65234 & 3.4742 & 3.8305 \\
\hline Brands functional benefit & 43.55 & 127 & 0.000 & 3.33984 & 3.1881 & 3.4916 \\
\hline
\end{tabular}

According to the calculated " $\mathrm{T}$ " in the above table which is significant, all they hypotheses were confirmed.

Table 3.

\begin{tabular}{|c|c|c|c|c|c|c|c|}
\hline Sig.(2-tailed) & $\begin{array}{l}\text { Logo } \\
\text { familiar } \\
\text { ity } \\
\text { benefit }\end{array}$ & $\begin{array}{l}\text { Logo } \\
\text { identifi } \\
\text { cation }\end{array}$ & $\begin{array}{l}\text { Brands } \\
\text { aesthetic } \\
\text { appeal }\end{array}$ & $\begin{array}{l}\text { Self-identity/expre } \\
\text { ssiveness of the } \\
\text { brand }\end{array}$ & $\begin{array}{l}\text { Brand } \\
\text { Commi } \\
\text { tment }\end{array}$ & $\begin{array}{l}\text { Brand } \\
\text { logos } \\
\text { visual } \\
\text { symbols }\end{array}$ & $\begin{array}{l}\text { Brands } \\
\text { functio } \\
\text { nal } \\
\text { benefit }\end{array}$ \\
\hline Logo familiarity benefit & 0 & & & & & & \\
\hline Logo identification & 0.000 & & & & & & \\
\hline Brands aesthetic appeal & 0.000 & 0.000 & & & & & \\
\hline $\begin{array}{l}\text { Self-identity/expressiven } \\
\text { ess of the brand }\end{array}$ & 0.000 & 0.000 & 0.000 & & & & \\
\hline Brand Commitment & 0.000 & 0.000 & 0.000 & 0.000 & & & \\
\hline $\begin{array}{l}\text { Brand logos visual } \\
\text { symbols }\end{array}$ & 0.000 & 0.000 & 0.000 & 0.000 & 0.000 & & \\
\hline $\begin{array}{ll}\text { Brands } & \text { functional } \\
\text { benefit } & \end{array}$ & 0.000 & 0.000 & 0.000 & 0.000 & 0.000 & 0.000 & 0 \\
\hline
\end{tabular}

This table shows spearman correlation of the research variables. The correlation among all variables is significant and 99 percent.

Hypothesis 1: There is a significant relationship between expressive ness benefit of Oil Company's brand and products brans performance.

Table 4.

\begin{tabular}{llll}
\hline Variable correlation & $\begin{array}{l}\text { Person } \\
\text { correlation }\end{array}$ & Significance & Interpretation \\
\hline $\begin{array}{l}\text { Expressiveness benefit of the Oil company's brand } \\
\text { and firm performance }\end{array}$ & 0.87 & 0.000 & $\begin{array}{l}\text { Positive and significant } \\
\text { correlation }\end{array}$ \\
\hline
\end{tabular}

The result of exploring hypothesis indicate that expressiveness benefit of the brand influences the Oil company's performance as a critical factory the impact is positive which means that the expressiveness benefit of the brand logo leads to the more quality of the Oil company's performance.

Hypothesis 2: There is a significant relationship between Oil Company's brand logo and the firm performance. 
Table 5 .

\begin{tabular}{llll}
\hline Variable correlation & Person correlation & Significance & Interpretation \\
\hline Brand logos benefits & 0.82 & 0.000 & Positive and significant correlation \\
\hline
\end{tabular}

The result of investigating this Hypothesis shows that the Oil Company's brand logo can be considered as a factor which impacts the firm performance positively and leads to high-quality performance.

Hypothesis 3: There is a significant relationship between Oil Company's aesthetic appeal and the firm's performance.

Table 6.

\begin{tabular}{llll}
\hline Variable correlation & Person correlation & Significance & Interpretation \\
\hline Brand logo's aesthetic appeal & 0.79 & 0.000 & Positive and significant correlation \\
\hline
\end{tabular}

The results indicate that the aesthetic appeal or the Oil Company impacts positively the firm performance. This effective factor can make the firm performance be of high quality.

Hypothesis 4: There is a significant relationship between brand logo's self-identity and the Oil Company's performance.

Table 7.

\begin{tabular}{llll}
\hline Variable correlation & Person correlation & Significance & Interpretation \\
\hline Brand logos self-identity & 0.86 & 0.000 & Positive and significant relationship \\
\hline
\end{tabular}

The above result indicates that Oil Company's brand self-identity influences the firm performance positively and is an effective factor in leading to high-quality of the Oil Company's performance.

Hypothesis 5: There is a significant relationship between brand's visuals symbols and the firm performance.

Table 8 .

\begin{tabular}{llll}
\hline Variable correlation & Person correlation & Significance & Interpretation \\
\hline Brand logo's visual symbols & 0.61 & 0.000 & Positive and significant relaionship \\
\hline
\end{tabular}

The tables say that visual symbols of the Oil Company's brand as an effective factor influences the firm performance.

This means that Oil company's brand visual symbols increase the firm performance quality.

Hypothesis 6: There is a significant relationship between Oil Company's commitment and its performance.

Table 9.

\begin{tabular}{llll}
\hline Variable correlation & Person correlation & Significance & Interpretation \\
\hline Brand commitment & 0.88 & 0.000 & Positive and significant correlation \\
\hline
\end{tabular}

The results indicate that brand commitment of Oil company products impact the firm performance positively. That is to say that the brand commitment leads to high-quality firm performance.

\section{Conclusion}

Business is a human activity which is constantly evaluated mentally and logically. Brand logos are considered as a part of marketing and therefore need to be evaluated. Logos by themselves are not good or bad; the firm decisions make them bad or good.

These decisions must be made based on various aspects of the brand logo's such as identify active benefit , self-identity, aesthetic appeal, expressiveness benefit, brand's visual symbols. The company must spend some 
expenses if not considering the informational aspects. Cones-quality, it can be said that Oil company's brand logo is important at two levels: first, at the level of brand logo's decision based on its expressiveness, self-identity, aesthetic appeal benefits and visual symbols. Second, at the functional level which concerns about the relationship between logo's different aspects and brand's customers commitment? However, this is a new hypothesis and requires more research and study. What's an evident company must have strategic and systematic view about their brands and their relationship with customers, create a reciprocal equation. There, the role of Oil Company's brand logo is critical to the extent that today's and future succen depend on correct familiarity with different aspects of brands which were mentioned previously. Companies can increase their sucess in today's competing markets via investing the effects of the brand factors on choosing the best one. The following are the fin days of the studying effecting variables in brand logos in Ilam Oil Company:

The participants of the study were 116 people, 91 per can't male, 101 people married. 45 people that is $35-44$ years old age and 28 percent are $45-54$ years old. 35 percent of them have got a bachelor degree and 36 people or 28 percent were diploma-the people who answered the questionnaire were both Oil company's staff and customers. 47 percent of them had 11-15 years' experience, 24 per cent 6-10 years.

After analyzing the data, the results indicate that all aspects of Oil Company's logo correlate positively with the firm performance. And their relationships were significant. However participants think this relationship according to the mean of table 34,37 is not so much high and this mean must be increased through rein-forcing a aforementioned log's aspects. On the other hand, the obtained scores demonstrate that participants may have answered the questions cautions since they were involved in writing questions. According to correlation numbers of the results, it is indicated that correlation between brand commitment (48.5), aesthetic appeal (47.6), brand logo's familiarity (46.4), brand self-identity (45.2), functional (43.6), brand logo's visual symbols (40.5) with Oil Company is brand logo's functions is very high.

\section{Suggestions Based on Research Findings}

The obtained results of correlation between brand commitment and different aspects of its benefits were reported. Based on these results, the following suggestions can be made:

- As there are many different nations in our country, so there might be some relation between brand familiarity and their languages in order to make some changes in the mind of customers.

- considering the aesthetic appeal aspect of brand logos, Oil Company would rather use signs that indicate clear and obvious meaning in brand logos.

- Considering self-indenting and expressiveness benefits of brands, what is written in logos can be based on native culture of nations culture of nations. Brands must be designed in a way that help to promote their success and help customers to buy the products for many times.

- Considering the Oil Company's products' brand commitment, some measures must be taken so as to increase the products. For instance the firm can reduce prices, the leads to keeping the relationship between products and customers' commitment.

- For the brand' visual symbol's, it is suggested to change or reform the symbols under the supervision of related experts.

\section{Suggestions for Further Studies}

As the topic of this study is somehow innovative and new and involves the help and support of professors and experts, the following are suggested to further studies:

In order to increase the effect of effectiveness of designing logos according their colors and size is suggested.

The above topic can be conducted in all the stores which sell the oil products with extensive aspects and fetors.

Considering the commercial aspect of Oil products and the importance of the topic throughout the world, customers must be trained through workshops, seminars, and conferences.

Oil Company had better to organize groups of experts and the brand's customers in order to organize groups of experts and the brand's customers in order to exchange their opinions and experiences.

Oil Company should try to hold annual fairs of its products for customers' convenience.

\section{Limitations of the Study}

This study, like any other research, suffers from some limitations, while the researcher did his best to reduce the effects of these limitations, the study come across the following: 
The first limitation relates to the measuring tools of study, that is the questionnaires. Most probably, different participants get the questions differently. The interview helped to clarify some points by expressing their experiencing and their attitudes toward the brand logos.

One of the obstacles that were encountered was the sharing of some variables among the six effective factors of brands: self-identity, expressiveness esthetic appeal, brand commitment, visual symbols, and familiarity. It was really challenging and difficult to distinguish variables. For example variable could be an effective factor in both visual symbols and esthetic appeal.

The sampling who included the experts of Oil Company and some of the customers who were always busing products was a very small population of the entire population. Therefore the study suffers from external validity. Investigating other customers opinions can lead to other useful results.

The study could not explore all the variables which are effective, It just investigated some important and critical ones.

\section{References}

Aaker, D. A. (1996). Building Strong Brands. New York: The Free Press.

Ailawadi, K. L., Lehmann, D. R., \& Neslin, S. A. (2003). Revenue premium as an outcome measure of brand equity. Journal of Marketing, 67, 1-17

Anderson, E. W., Fornell, C., \& Mazvancheryl, S. K. (2004). Customer satisfaction and shareholder value. Journal of Marketing, 68, 172-185.

Barth, M. E., Clement, M. B., Foster, G., \& Kasznik, R. (2003). Brand value and capital market valuation. In Hand, J., \& Lev, B. (Eds.), Intangible assets (pp. 153-184). New York, NY: Oxford University Press.

Baumgartner, H., \& Steenkamp, J. B. (2006). Response biases in marketing research. In Grover, R., \& Vriens, M. (Eds.), The handbook of marketing research (pp. 95-109). Thousand Oaks, CA: Sage Publications.

Bhattacharya, C. B., \& Sen, S. (2003). Customer-company identification: A framework for understanding customers' relationships with companies. Journal of Marketing, 67, 76-88.

Brown, W. F. (1942). The determination of factors influencing brand choice. The National Convention of the American Marketing Association, New York.

Chaplin, L. N., \& Roedder John, D. (2005). The development of self-brand connections in children and adolescents. Journal of Consumer Research, 32, 119-129.

Chong, M. (2007). The role of internal communication and training in infusing corporate values and delivering brand promise: Singapore Airlines' experience. Corporate Reputation Review, 10(3), 2007.

De Chernatony L. (2001). From Brand Vision to Brand Evaluation. Butterworth \& Heinemann: Oxford, 2001.

De Wulf, K., Odekerken, S. G., \& Iacobucci, D. (2001). Investments in customer relationships: A cross-country and cross-industry exploration. Journal of Marketing, 65, 33-50.

Eisingerich, A. B., \& Rubera, G. (2010). Drivers of brand commitment: A cross-national investigation. Journal of International Marketing, 18, 64-79.

Escalas, J. E., \& Bettman, J. R. (2005). Self-construal, reference groups, and brand meaning. Journal of Consumer Research, 32, 378-389.

Gapp, R., \& Merrilees, B. (2006). Important factors to consider when using internal branding as a management strategy: A healthcare case study. Journal of Brand Management, 14, 2006.

Goldman, A. H. (2005). The aesthetic. In Gaut, B., \& Lopes, D. M. (Eds.), The Routledge companion to aesthetics (pp. 255-266). New York, NY: Routledge Publishing.

Goldman, R., \& Papson, S. (1998). Nike culture. Thousand Oaks, CA: Sage Publications.

Luo, X., \& Bhattacharya, C. B. (2006). Corporate social responsibility, customer satisfaction, and market value. Journal of Marketing, 70, 1-18.

Morgan, N. A., \& Rego, L. L. (2009). Brand portfolio strategy and firm performance. Journal of Marketing, 73, 59-74.

Müller, B., Kocher, B., \& Crettaz, A. (2011). The effects of visual rejuvenation through brand logos. Journal of Business Research. http://dx.doi.org/10.1016/j.jbusres.2011.07.026. 
Papasolomou, I., \& Vronits, D. (2006). Using internal marketing to ignite the corporate brand: The case of the UK retail bank industry. Journal of Brand Management, 14(1/2), 2006.

Park, C. W., MacInnis, D. J., \& Priester, J. (2006). Brand attachment: Construct, consequences and causes. Foundations and Trends in Marketing, 1(3), 190-230.

Park, C. W., MacInnis, D. J., Priester, J., Eisingerich, A. B., \& Iacobucci, D. (2010). Brand attachment and brand attitude strength: Conceptual and empirical differentiation of two critical brand equity drivers. Journal of Marketing, 74, 1-18.

Pittard, N., Ewing, M., \& Jevons, C. (2007). Aesthetic theory and logo design: Examining consumer response to proportion across cultures. International Marketing Review, 24(4), 457-473.

Rao, V. R., Agarwal, M. K., \& Dahlhoff, D. (2004). How is manifest branding strategy related to the intangible value of a corporation? Journal of Marketing, 68, 126-141.

Rothe, T. J., \& Lamont, M. L. (1973), Purchase behavior and brand choice determinants for national and private brand: major appliances. Journal of Retailing, 49(3), 19-33.

Schau, H. J., Muñiz, A. M. Jr., \& Arnould, E. J. (2009). How brand community practices create value. Journal of Marketing, 73, 30-51.

Van Den Bosch, A. L. M., De Jong, M. D. T., \& Elving, W. J. L. (2005). How corporate visual identity supports reputation. Corporate Communications, 10(2), 108-116.

Walsh, M. F., Winterich, K. P., \& Mittal, V. (2010). Do logo redesigns help or hurt your brand? The role of brand commitment. The Journal of Product and Brand Management, 19(2), 76-84.

Whan Park, A., Andreas, B., Eisingerich, B., Gratiana Pol, A., \& Jason Whan Park (2013). The role of brand logos in firm performance. Journal of Business Research, 66(2013), 180-187.

Woo, J. J., Chang Hoan, C., \& Hyuck Joon, K. (2008). The role of affect and cognition in consumer evaluations of corporate visual identity: Perspectives from the United States and Korea. Journal of Brand Management, 15(6), 382-398.

\section{Copyrights}

Copyright for this article is retained by the author(s), with first publication rights granted to the journal.

This is an open-access article distributed under the terms and conditions of the Creative Commons Attribution license (http://creativecommons.org/licenses/by/4.0/). 